\begin{tabular}{|c|c|c|}
\hline Beitr. Ent. & Keltern & ISSN 0005-805X \\
\hline $\mathbf{5 7}(2007) 2$ & S. $355-366$ & 21.12 .2007 \\
\hline
\end{tabular}

\title{
Proteinus crenulatus - a complex of five species
}

\section{(Coleoptera: Staphylinidae: Proteininae)}

With 21 figures and 2 maps

Volker Assing

\section{Summary}

A revision of types and additional material revealed that what has previously been interpreted as Proteinus crenulatus PANDellé, 1867 is in fact a complex of five similar species: $P$. crenulatus (widespread in Europe), P. abditus sp. n. (Germany, Romania), P. hamatus sp. n. (N-Spain, SW-France), P. tronqueti sp. n. (Corsica), and $P$. angulatus sp. n. (S-Italy, S-Greece). The distinguishing characters are described and illustrated. A lectotype is designated for $P$. crenulatus PANDellé. The distributions of all five species are mapped.

Key words

Coleoptera, Staphylinidae, Proteininae, Proteinus, Western Palaearctis, taxonomy, lectotype designation.

New species

Proteinus abditus sp. n., P. angulatus sp. n., P. hamatus sp. n., P. tronqueti sp. n.

\section{Zusammenfassung}

Eine Revision von Typen und weiterem Material ergab, dass die bisherige Deutung von Proteinus crenulatus PANDellé, 1867 einen Komplex aus fünf ähnlichen Arten umfasst: $P$. crenulatus (weitverbreitet in Europa), P. abditus sp. n. (Deutschland, Rumänien), P. hamatus sp. n. (N-Spanien, SW-Frankreich), P. tronqueti sp. $\mathrm{n}$. (Korsika) sowie $P$. angulatus sp. n. (S-Italien, S-Griechenland). Differentialmerkmale werden beschrieben und abgebildet. Für P. crenulatus PANDellé wird ein Lectotypus designiert. Die derzeit bekannte Verbreitung aller Arten wird anhand von Karten veranschaulicht.

\section{Introduction}

Disregarding two nomina dubia (P. hibernus Gistel, 1857 and P. minutus Mannerheim, 1830), the genus Proteinus Latreille, 1797 currently includes 36 valid names. 34 species are distributed in the Palaearctic and Nearctic regions, with some widespread species also occurring in parts of the Ethiopian and Oriental regions; two species were described from Central America. In the Palaearctic region, the genus is represented by 26 species, eleven of them confined to the Western Palaearctic (including Middle Asia), ten to the Eastern Palaearctic region, and five species with a trans-Palaearctic distribution (Assing 2004; Herman 2001; Smetana 2004). A number of species (e. g. P. brachypterus (FABricius, 1792)) have vast distribution ranges and are common almost everywhere; some species, on the other hand, appear to have restricted distributions (e. g. P. siculus Dodero, 1923 and P. creticus Assing, 2004) or are collected only rarely. 
Owing to the overall external similarity and weakly pronounced character divergence, a reliable identification of many Proteinus species is possible only based on the male sexual characters, especially the morphology of the aedeagus and often also the modified protarsi, as well as the meso- and metatibiae, and occasionally also the mesotrochanter; for recent illustrations see e. $\mathrm{g}$. Dauphin (1995a, 1995b, 1999) and Assing (2004).

Proteinus crenulatus PANDellé, 1867, a species without junior synonyms (Herman 2001; SMETANA 2004), has been reported from approximately 20 European countries and even from Kazakhstan (Herman 2001; Smetana 2004), but is generally considered one of the rarer species (Dauphin 1995a; Horion 1963; Lohse 1964). According to Lohse (1964) and Dauphin (1995a), it is characterised by the following character combination: antennae uniformly black, relatively long, and with moderately transverse preapical antennomeres (antennomere $\mathrm{X}$ less than twice as wide as long); mesosternum with (anteriorly not bifid) median carina; pronotum with relatively shallow microsculpture and not completely matt; male protasomere I distinctly elongated and approximately as long as the combined length of protarsomeres II-V; male meso- and metatibia with approximately 12 black tubercles; male mesotibia curved; slender aedeagus with apically bent and acute ventral process. The species has often been confused with P. ovalis STEPHENs, 1834 and also with P. brachypterus (DaupHin 1995a; Horion 1963).

The present study was initiated by an examination of some Proteinus specimens from northern Spain. The aedeagus was of somewhat similar general morphology as that of material from Germany, but there were clear differences especially in the shape of the apex of the ventral process and in the internal structures. In the course of an ensuing closer inspection of the morphology of the aedeagus of all the specimens previously identified by me as $P$. crenulatus four different species could be distinguished. A subsequent study of material of $P$. "crenulatus" from various public and private collections, including the type material of the true $P$. crenulatus, eventually revealed that the $P$. crenulatus of earlier authors is in fact a complex of (at least?) five species. These results suggest that a thorough revision of other species groups of Proteinus may yield even further previously undetected species.

\section{Material and methods}

The material referred to in this study is deposited in the following public and private collections:

$\begin{array}{ll}\text { DEI } & \text { Deutsches Entomologisches Institut, Müncheberg (L. Zerche, L. Behne) } \\ \text { IRSNB } & \text { Institut royal des Sciences naturelles de Belgique, Bruxelles (Y. Gérard) } \\ \text { MHNG } & \text { Muséum d'histoire naturelle Genève (G. Cuccodoro) } \\ \text { MNHUB } & \text { Museum für Naturkunde der Humboldt -Universität Berlin (J. Frisch, J. Willers) } \\ \text { NHMW } & \text { Naturhistorisches Museum Wien (H. Schillhammer) } \\ \text { SMNS } & \text { Staatliches Museum für Naturkunde Stuttgart (W. Schawaller) } \\ \text { cAss } & \text { author's private collection } \\ \text { cFel } & \text { private collection Benedikt Feldmann, Münster } \\ \text { cKöh } & \text { private collection Frank Köhler, Bornheim } \\ \text { cRen } & \text { private collection Klaus Renner, Bielefeld } \\ \text { cSch } & \text { private collection Michael Schülke, Berlin } \\ \text { cScm } & \text { private collection Ludger Schmidt, Hannover } \\ \text { cTro } & \text { private collection Marc Tronquet, Molitg-les-Bains } \\ \text { cVog } & \text { private collection Jürgen Vogel, Görlitz } \\ \text { cWun } & \text { private collection Paul Wunderle, Mönchengladbach } \\ \text { cZan } & \text { private collection Adriano Zanetti, Verona }\end{array}$


The morphological studies were carried out using a Stemi SV 11 microscope (Zeiss Germany) and a Jenalab compound microscope (Carl Zeiss Jena) with a drawing tube. For the photographs a digital camera (Nikon Coolpix 995) was used.

The maps were generated using the online generic mapping tool (GMT) of the Geomar website at www. aquarius.ifm-geomar.de/omc.

\section{Species descriptions}

In view of the extremely similar external morphology of all the species treated below, only Proteinus crenulatus is (re-)described in detail, and the descriptions of the new species are confined to distinguishing characters. Also, a key to species is not provided, since a reliable identification of the species of the $P$. crenulatus group exclusively relies on the morphology of the aedeagus. The internal structures and other important features of the aedeagus are best seen in transparent light and with a compound microscope.

\section{Proteinus crenulatus PANDellé, 1867 (Figs 1-6, Map 1)}

Proteinus crenulatus PANdellé, 1867: 169.

\section{Type material examined:}

Lectotype o , here designated: "§ 3315. / Syntype / 3315. Proteinus, Latreille, crenulatus Pand., Louron / Coll. R. I Sc. N. B, ex Coll. Pand. / Lectotypus ơ Proteinus crenulatus Pandellé desig. V. Assing 2007" (IRSNB). Paralectotypes: $40^{\star} 0^{\star}, 4$ 우 우 : same data as lectotype (IRSNB); $10^{\star}$, 1 ㅇ: "crenulatus, H. Pyrénées / Pand. / coll. Heyden / Hubenthal det. / Syntypus / DEI, coll. von Heyden / Proteinus crenulatus Pand. / coll. DEI Müncheberg" (DEI); 2 ㅇ 우: "crenulatus Pand. Ht. Pyr. / coll. Kraatz / coll. DEI Müncheberg" (DEI).

\section{Comment:}

The original description is based on an unspecified number of syntypes from "H.-Pyrénées, Louron" (PANDELlé 1867). One of the males in the collection of the IRSNB is here designated as the lectotype.

Additional material examined: Scotland: $10^{x}, 1$, Inverness-Shire, Loch-Garten, X.1985, leg. Owen (cSch).

Norway: $20^{\star} 0^{\star}, 2$ 우, Røa, Vestre Aker, 19.IX.1937, leg. Strand (NHMW, cAss); $20^{\star} 0^{\star}$, Gaustad V. A., 31.VIII.1933 (NHMW, cAss); $10^{*}$, Gaustad V. A., IX.1929, leg. Strand (NHMW); 1 우, Asker, 20.V.1924 (NHMW).

Spain: $20^{\star} 0^{\star}$, Navarra, Bosque del Irati, between Artzapar and Col Orión, 900 m, 20.VII.1996, leg. Wrase (cSch, cAss).

France: Languedoc-Roussillon: $10^{\star}$, Pyrénées-Orientales, Massif du Madres, La Balmette, marmot burrow, 20.VI.1997, leg. Tronquet (cTro). Franche-Comté: $10^{\prime}$, Malbouisson, on the wing (18 h), 4.VII.1972, leg.

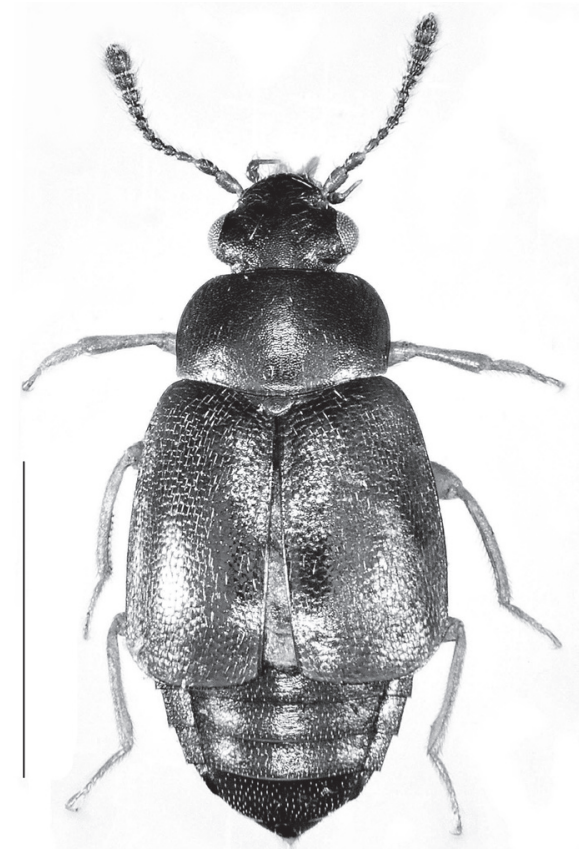

Fig. 1: Proteinus crenulatus Pandellé: habitus (photo by Marc Tronquet). Scale: $1.0 \mathrm{~mm}$. 
Tronquet (cAss); $10^{\star}, 2$ 우 옹 same data, but 7.VII.1972 (cTro); $10^{\star}$, same data, but 8.VII.1972 (cTro); $10^{\star}$, Jura, NE Champagnole, Forêt de la Joux, on the wing (17 h), 23.VII.1972, leg. Tronquet (cTro). Rhône-

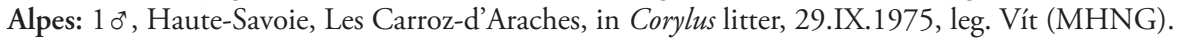

Germany: Nordrhein-Westfalen: $10^{\star}$, Menden, Hönnetal, NSG Klusenstein, 25.XI.1995, leg. Feldmann (cFel); $10^{\star}$, Aachen, Grüne Eiche, mushrooms, 1.XI.1983, leg. Wunderle (cWun); $20^{\star} \sigma^{\star}$, Eifel, near Röttgen, mushrooms, 13.X.1983, leg. Wunderle (cWun, cAss); $10^{\star}$, Bielefeld, Teutoburger Wald, HobergeUerentrup, compost sifted, 5.XII.1978, leg. Renner (cRen); $10^{\star}$, Bielefeld, 5.XII.1978, leg. Renner (cKöh); $10^{\star}$, Bielefeld, 7.XI.1975, leg Renner (cRen). Baden-Württemberg: $10^{\star}, 1$ 우, Löwensteiner Berge, 500 m, 25.X.1965, leg. Ulbrich (SMNS); $1 \sigma^{\star}$, Kreis Öhringen, Neuhütten, Mainhardter Wald, 15.X.1978, leg. Ulbrich (SMNS). Rheinland-Pfalz: $2 \sigma^{\star} \sigma^{\star}$, Bayerfeld, Bayerfeldstollen, pitfall trap, VIII.-X.2006, leg. Weber (cFel); $10^{\star}$, Altenahr, Langfigtal, 3.VII.1986, leg. Wunderle (cWun); $10^{\star}$, SE Simmern, Soonwald [ca. $49^{\circ} 55^{\prime} \mathrm{N}, 7^{\circ} 35^{\prime} \mathrm{E}$ ], Kelierbachtal, 4.VIII.1987, leg. Wunderle (cWun), $20^{\star} 0^{\star}, 2$ 우 우, Taben/Saar, Urwald von Taben, 8.X.1996, leg. Köhler (cKöh, cAss). Niedersachsen: $10^{\star}$, S Hildesheim, Diekholzen, Kalte Beuster, 27.III.2003, leg. Schmidt (cScm). Hessen: $10^{\star}, 1$ \% , Marburg, badger burrows, 12.X.1985, leg. Wunderle (cWun); $10^{\star}$, same data, but 6.X.1985 (cWun); $30^{\star} 0^{\star}, 3$ 우 ㅇ, Nentershausen, Naturwaldreservat GoldbachZiehba, XI.1995, leg. Flechtner (cKöh, cAss); $10^{\star}$, same data, but X.1994 (cKöh); $10^{\star}, 1$ ․ Schlitz, Limnologische Station, XI.1987, leg. Wunderle (cZan). Bayern: $1 \sigma^{*}$, Naturpark Altmühltal, pitfall trap, VI.1997, leg. Hendricks (cAss). Sachsen: $10^{\star}$, Zittau, Lausche, 25.V.1989, leg. Vogel (cVog); $10^{*}$, Auerbach, 27.XI.1974, leg. Kaufmann (cVog); $10^{\star}$, same data, but 9.X.1981 (SMNS); $10^{\star}$, Bärenburg [50 48'N, $13^{\circ} 43^{\prime} \mathrm{E}$ ], leg. Vogel (SMNS); $10^{\star}$, Dresden, Pillnitz, NSG Borsberghänge/Friedrichsgrund, X.2001, leg. Lorenz (cVog).

Italy: Trentino-Alto Adige: $1 \sigma^{\star}$, Val di Non, NE Coredo, Val di Verdès, 1000 m, 12.VIII.1998, leg. Assing (cAss); 1 ex., Val di Non, Verdès, 1000 m, car-net, 1.VIII.1996, leg. Zanetti (cZan). Liguria: $10^{*}$, Fontanigorda (GE), Monte Montarlone, 1200 m, 3.X./8.XI.1991, leg. Gatti (cZan). Basilicata: $10^{\text {* }}$, La Maddalena, Abriola (PZ), $1330 \mathrm{~m}$, beech forest, sifted, 13.VI.1988, leg. Angelini (cZan). Calabria: $10^{\star}$, La Sila, Mt. Botte Donato (CS) [39 $\left.17^{\prime} \mathrm{N} ; 16^{\circ} 27^{\prime} \mathrm{E}\right], 1500 \mathrm{~m}, 14 . \mathrm{X} .1978$, leg. Montemurro (cZan); 3 ㅇ ㅇ, same data, but $1900 \mathrm{~m}$ (cZan); $20^{\star} o^{\star}$, La Sila, Lorica, 1300 m, 10.-15.X.1978, leg. Angelini (cZan); $20^{\star} o^{\star}$, La Sila, Camigliatello, Fossiata (CS), 1400 m, 2.VII.1987, leg. Angelini (cZan, cAss); $10^{\star}, 2$ 우 오 La Sila, Croce Magara, 1300 m, 4.VII.1987, leg. Angelini (cZan).

Bulgaria: $1 \sigma^{\star}$, Rhodopi, De Smolian, near grotte d'Ushiovisa, 885 m, 28.V.2005, leg. Hlaváč (cTro).

Greece: $2 \sigma^{\top} \sigma^{\prime}$, Makedhonia, Pieria Ori, above Skotina, $40^{\circ} 12^{\prime} \mathrm{N}, 22^{\circ} 10^{\prime} \mathrm{E}, 900-1000 \mathrm{~m}$, leaf litter sifted, 9.IV.1998, leg. Assing (cAss).

\section{Redescription:}

Size variable, length of body 2.1-2.7 mm (abdomen extended); width of pronotum 0.55-0.70 mm. Habitus as in Fig. 1. Coloration: body black; legs yellowish brown; antennae blackish, often with the basal antennomeres more or less distinctly paler.

Antennae relatively slender, approximately 1.5 times as long as width of head across eyes, antennomeres IV-VII approximately as long as wide; VIII weakly transverse; X approximately 1.5 times as wide as long (see figure 7 in Dauphin 1995a).

Pronotoum approximately 1.65 times as wide as long and 1.35-1.45 times as wide as head; anteriorly and laterally distinctly margined; posteriorly usually not margined, sometimes indistinctly margined; posterior angles obtusely angled; surface with distinct microsculpture composed of isodiametric meshes and with subdued shine; puncturation fine and sparse, barely noticeably in the microreticulation.

Elytra at suture 1.90-2.05 times as long and 1.4-1.5 times as wide as pronotum; puncturation dense and distinctly coarser than that of pronotum; interstices with or without very shallow microsculpture, shiny. Hind wings fully developed. Mesosternal process with simple (i. e. anteriorly not bifid) median carina. All legs with sexual dimorphism. 

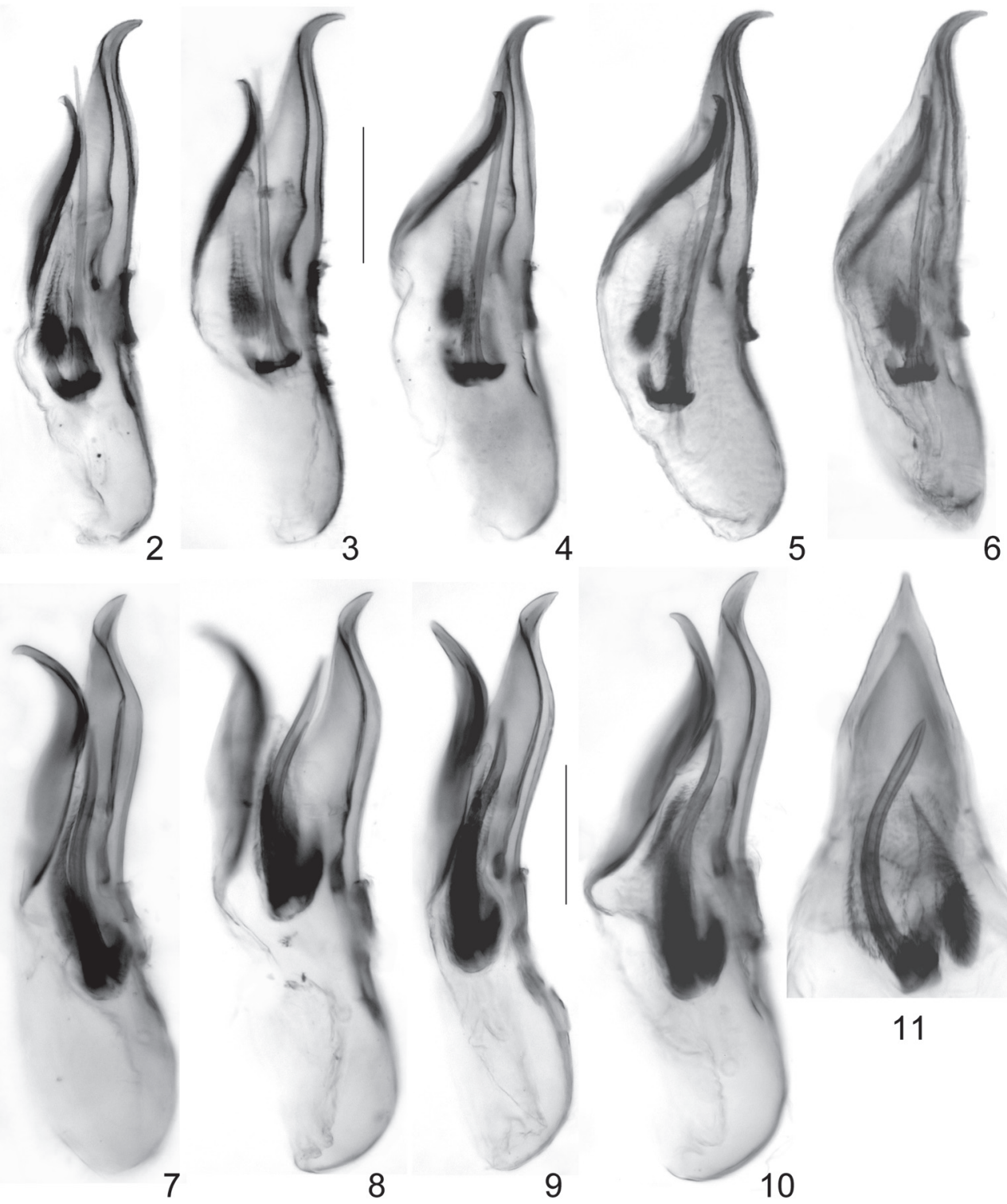

Figs 2-11: Proteinus crenulatus PAndellé (2-6) and P. abditus sp. n. (7-11): aedeagus in lateral view (2-10) of males from France (2-3; 2: lectotype), northern Spain (4), northern Italy (5), northern Greece (6), Germany (7-9; 7: holotype; 8: Hessen; 9: Thüringen), and Romania (10); apical part of aedeagus in dorsal view of male from Romania (11). Scale bars: $0.1 \mathrm{~mm}$.

Abdomen with fine microsculpture and with moderately dense and extremely fine, barely noticeable puncturation; pubescence pale and very short, barely noticeable.

$\sigma^{\star}$ : protarsomere I conspicuously elongated and enlarged, approximately as long as combined length of protarsomeres II-V and distinctly wider than all other tarsomeres; mesotibia somewhat dilated in the middle and slightly curved in apical third (Fig. 1), internal face (i. e. area facing 
body) flattened and furnished with 9-12 blackish tubercles, external face with shallow furrow; metatibia somewhat dilated apically amd weakly curved, internal face flattened, but without tubercles, external face with shallow furrow; sternite VIII with U-shaped posterior excision, margin of this excision furnished with modified setae. Aedeagus approximately $0.40 \mathrm{~mm}$ long, slender, with apically curved and acute ventral process; dorsal plate weakly curved in lateral view; internal sac with rather long, thin, and straight flagellum (Figs 2-5).

ㅇ: for an illustration of the terminalia see figure 35 in DAuphin (1995a).

\section{Distribution and bionomics:}

Proteinus crenulatus has been reported from practically all of Europe, from the Iberian peninsula to the Caucasus region and including Scandinavia (Norway, Sweden, Finland); there is even a record from Kazakhstan (Herman 2001; Horion 1963; Smetana 2004). Records from Ukraine (Gusarov 1989) are listed by neither Herman (2001) nor Smetana (2004). However, since it has been confounded with at least four other species, all previous records have to be reexamined. The true Proteinus crenulatus is evidently more common and more widespread than any of the similar species described below. Based on the material examined, confirmed records are here reported

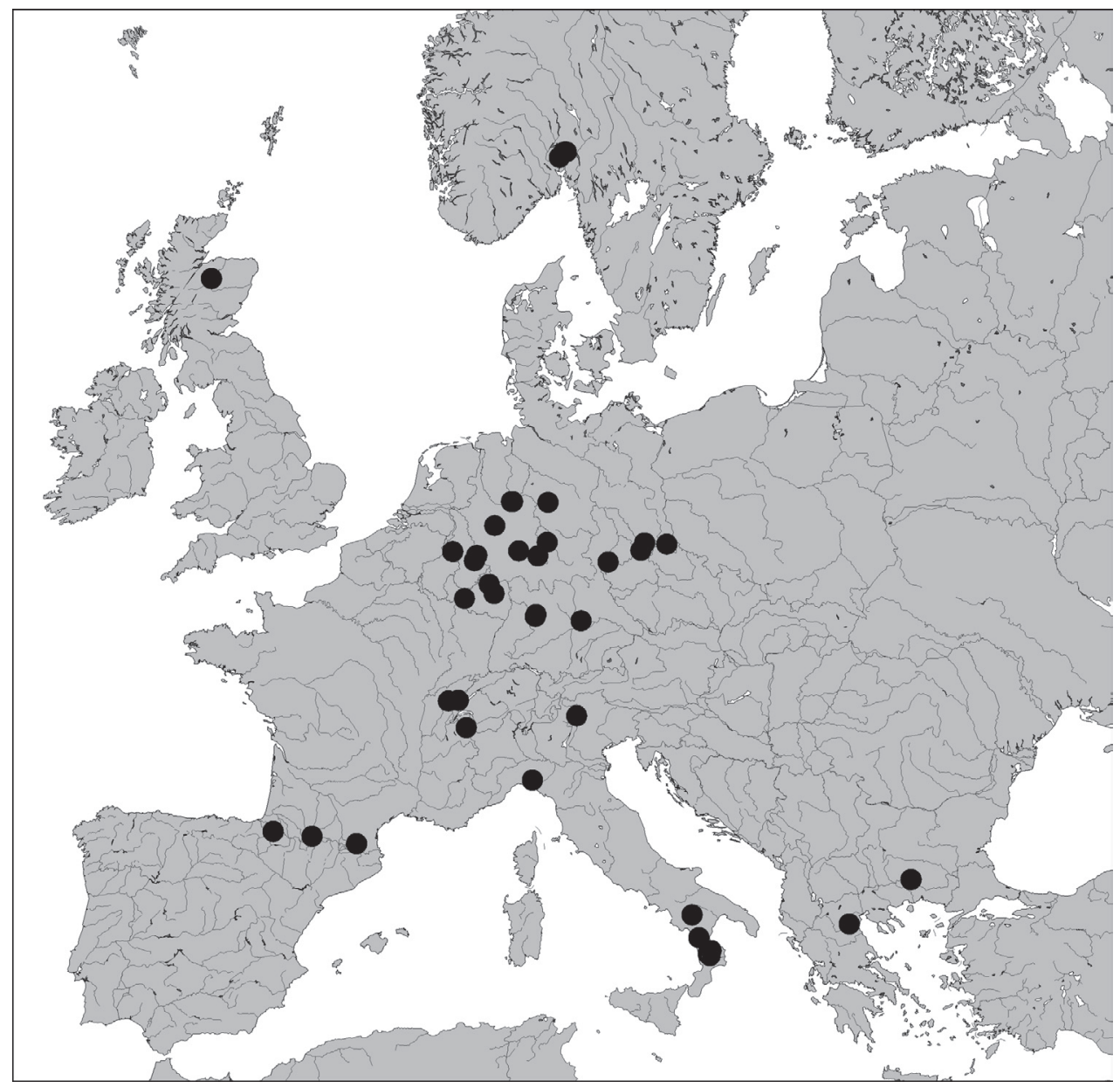

Map 1: Distribution of Proteinus crenulatus PANDellé in Europe, based on examined records. 
from northern Spain, Great Britain, Norway, France, Germany, Italy, Bulgaria, and northern Greece (Map 1). The available evidence suggests that the distribution may be of the expansive ponto-Mediterranean type (LATTIN 1967), but more data are needed to support this hypothesis.

Like the zoogeographic literature data, all previous ecological observations require revision. The above material was collected in a wide range of habitats by pitfall trapping, by sifting the litter of deciduous trees (beech, hazelnut), mushrooms, compost, and by sampling the burrows of badgers and marmot. On four occasions in July and August, flying specimens were caught with a car-net. The altitudes range from near sea-level up to $1900 \mathrm{~m}$. Adult beetles were collected from March through December, with the majority of specimens taken during the period from July through November and a maximum in October: March (1 specimen/1 sample), April (2/1) May (3/3), June (3/3), July (13/7), August (6/5), September (6/3), October (23/13), November (12/6), December (2/1). According to Duverger (1995), P. crenulatus is parasitised by the fungus Rickia proteini Melewsky, 1986 (Laboulbeniales), but again the identity of the host requires confirmation.

Proteinus abditus sp. n. (Figs 7-12, Map 2)

\section{Type material:}

Holotype ơ: "22.10.85, Marburg, Dachsbau, leg. Wunderle / Holotypus ơ Proteinus abditus sp. n. det. V. Assing 2007" (cAss). Paratypes: $10^{\star}$ : same data as holotype, but "12.10.85" (cAss); $10^{\star}$ : same data as holotype, but "15.10.85" (cWun); $10^{\text {* }}$ : "Leutra b. Jena, 31.10.88, Malt /

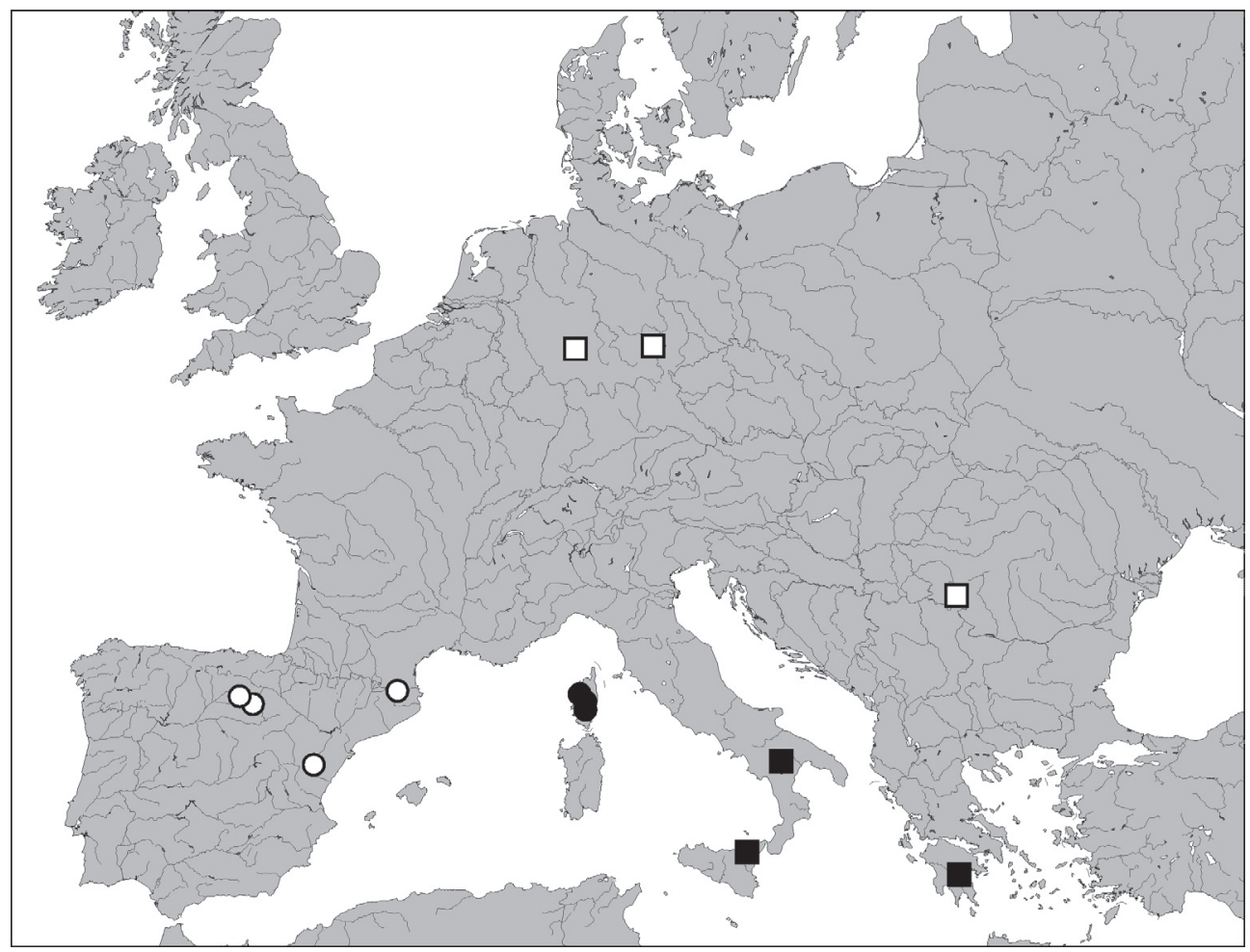

Map 2: Distributions of Proteinus abditus sp. n. (open squares), P. angulatus sp. n. (filled squares), P. hamatus sp. n. (open circles), and $P$. tronqueti sp. n. (filled circles) in Europe. 
Proteinus cruentatus [sic] det. J. Vogel" (cVog); $10^{\star}:$ "Herkulesbad, Mosoroni, 14.8.33 / Proteinus brachypterus det. Hänel / Proteinus crenulatus Pand., P. Dauphin det. 99" (MNHUB).

Material probably referring to this species, but not included in the type series: Romania: 1 ㅇ: "Herkulesbad, Mosoroni, 14.8.33" ("MNNUB); 1 \%: "Herkulesbad, Mosoroni, 7.6.32" (MNHUB); 1 우 : Herkulesbad, Pve. Musironi, 15.5.31" (MNHUB).

\section{Description:}

Body length 2.3-2.6 mm; width of pronotum 0.65-0.75 mm. Pronotum 1.70-1.75 times as wide as long. External morphology, including the male secondary sexual characters, as in P. crenulatus, except for the slightly more transverse pronotum; reliably distinguished only by the morphology of the aedeagus.

$\sigma^{\top}$ : aedeagus larger, approximately $0.45-0.48 \mathrm{~mm}$ long; ventral process strongly sinuate in lateral view and apically weakly bent; dorsal plate large, strongly bent and with acute apex in lateral view; flagellum stout, short, bent both in lateral and in ventral view, and more distinctly sclerotised than in P. crenulatus (Figs 7-12).

Etymology: The name (Latin, adjective: hidden, secret, cryptic) refers to the subterraneous habitat where some of the types were collected, as well as to the fact that this species has remained undiscovered so long even in Central Europe.

\section{Comparative notes:}

From other species of the $P$. crenulatus group, this species is reliably separated only based on the morphology of the aedeagus, especially the shape of the apex of the ventral process, of the flagellum in the internal sac, and of the dorsal plate.

\section{Distribution and bionomics:}

The known distribution of P. abditus is confined to Germany (two localities) and Romania (1 locality) (Map 2). The type specimens from Marburg were collected by baiting badger burrows.

\section{Proteinus angulatus sp. n. (Figs 13-17, Map 2)}

\section{Type material:}

Holotype ơ : "GR - Pelopónnisos, 40 km SE Tripoli, SW Ag. Petros, 1100 m, 37¹8'49N, 22³0'37E, 22.III.1997, V. Assing / Holotypus ơ Proteinus angulatus sp. n. det. V. Assing 2007" (cAss). Paratypes: $1 \sigma^{\star}$ : "Sicilia, Ragusa, ex coll. Eppelsheim" (NHMW); $40^{\star} \sigma^{\star}, 3$ 우 + : "For. Malabotta (Floresta-ME), leg. Brandmayr / M1 24.5.81, Aquifolio-Fagetum" (cZan, cAss); $10^{\star}, 2$ ㅇ $q$ : same data, but "M10" (cZan); 2 우 오 : same data, but "30.V.82" (cZan); $10^{*}, 4$ 우 우: "Basilicata, Accettura b. Montepiano (MT), 1050 m, 14.V.1989, leg. F. Angelini, Staz. 11, sp. n. 52 (cZan, cAss).

\section{Description:}

Of relatively small average size; body length 2.1-2.5 mm (abdomen extended); width of pronotum 0.6-0.7 mm; pronotum 1.70-1.75 times as wide as long. External morphology, including the male secondary sexual characters, as in $P$. crenulatus, except for the slightly more transverse pronotum; reliably distinguished only by the morphology of the aedeagus.

$0^{\text {t: }}$ aedeagus $0.41-0.44 \mathrm{~mm}$ long; ventral process distinctly sinuate in lateral view (similar to condition in $P$. abditus) and apically somewhat angled; dorsal plate strongly bent in lateral view and apically of characteristic shape (lateral view); flagellum almost straight, shorter and less slender than in P. crenulatus (Figs. 13-17). 


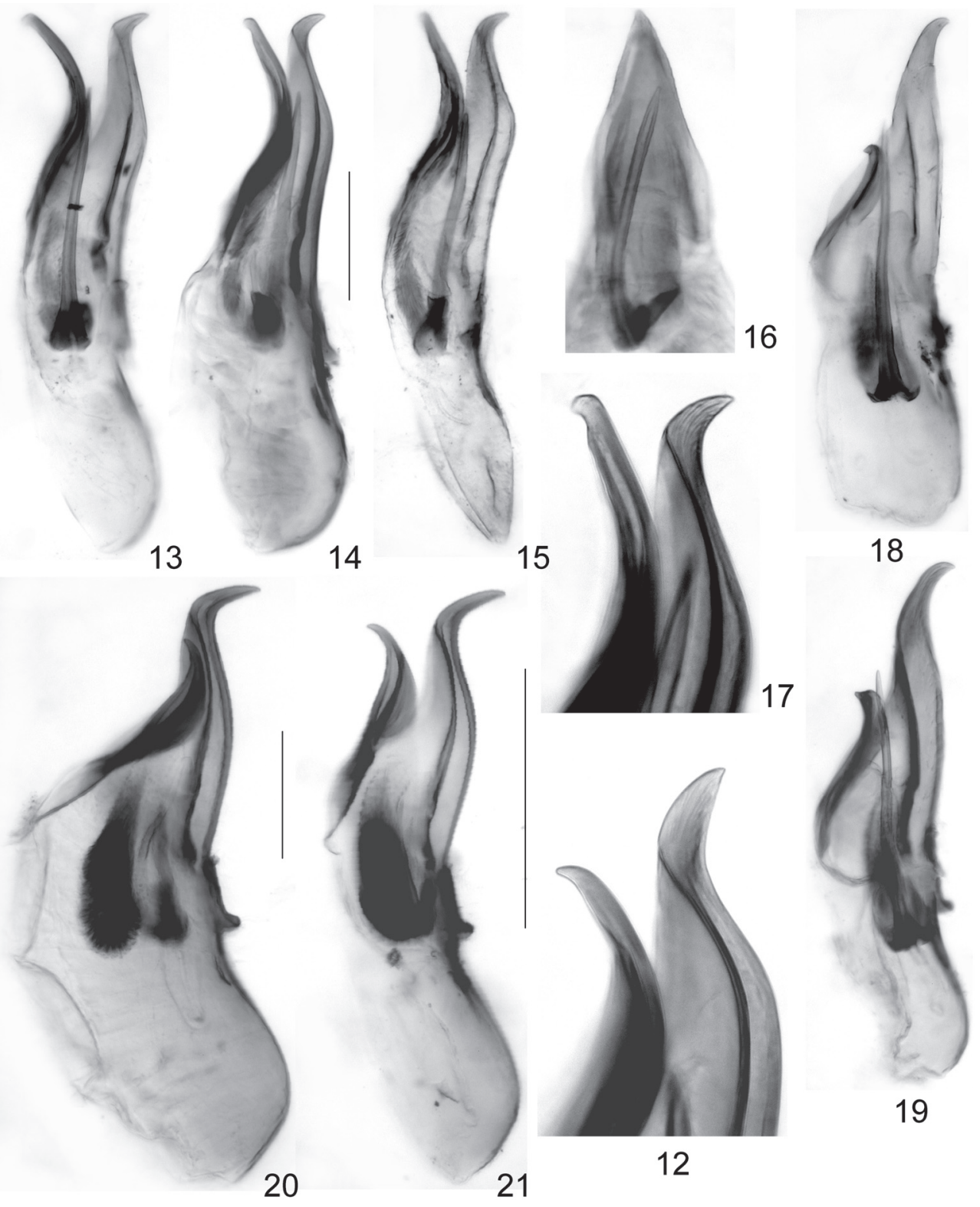

Figs 12-21: Proteinus abditus sp. n. (12), P. angulatus sp. n. (13-17), P. tronqueti sp. n. (18-19), and P. hamatus sp. n. (20-21): apical part of aedeagus in lateral view $(12,17)$; aedeagus in lateral view $(13-15,18-21)$ of males from Greece (13; holotype), Sicily (14), Basilicata (15), Corsica (18-19; 18: holotype), northern Spain (20; holotype), and southwestern France (21); apical part of aedeagus in dorsal view (16). Scale bars: $0.1 \mathrm{~mm}$. 
Etymology: The name (Latin, adjective: angled) refers to the shape of the aedeagal apex.

\section{Comparative notes:}

Among the species of the $P$. crenulatus group, the aedeagus is most similar to that of $P$. abditus, but distinguished by the angled apex of the ventral process (compare Figs 12 and 17), the less stout, less strongly sclerotised, and straight flagellum (compare Figs 7-11 and 13-16), the shape of the apex of the dorsal plate (compare Figs 12 and 17), as well as by the slightly smaller size.

\section{Distribution and bionomics:}

The species is currently known only from the Pelopónnisos (Greece), as well as from Basilicata and Sicily (Italy) (Map 2). The holotype was sifted from the leaf litter in an oak forest with Erica undergrowth; at least part of the paratypes from Sicily were collected in beech forests. As far as is specified on the labels, the specimens were collected in March and May at intermediate altitudes (1050-1100 m).

Proteinus tronqueti sp. n. (Figs 18-19, Map 2)

\section{Type material:}

Holotype ơ: "Forêt Valdo-Niello [= Forêt de Valdu-Niellu, ca. $42^{\circ} 18^{\prime} \mathrm{N}, 8^{\circ} 55^{\prime} \mathrm{E}$ ], 24.V.1972, M. Tronquet / au vol le soir / Holotypus ơ Proteinus tronqueti sp. n. det. V. Assing 2007"

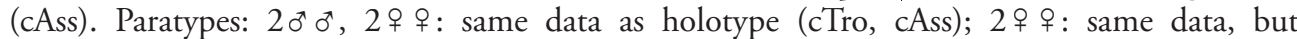
"25.5.1972"(cTro); $10^{\star}$ : "Zicavo (20), 31.5.72, M. Tronquet / au vol entre B. d. Cosciones e Col

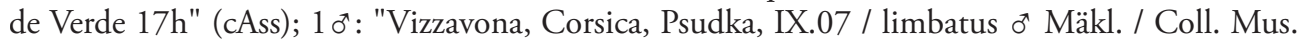
Vindob." (NHMW); 3 ㅇ : "Corsica, Vizzavona, Coll. O. Leonhard / Prot. limbatus / Hubenthal det. / Proteinus crenulatus Pand." (DEI, cAss).

\section{Description:}

Body length 2.1-2.5 mm (abdomen extended); width of pronotum 0.6-0.7 mm; pronotum 1.601.70 times as wide as long. External morphology, including the male secondary sexual characters, as in $P$. crenulatus; distinguished only by the morphology of the aedeagus.

$0^{\text {t }}$ : aedeagus $0.41-0.43 \mathrm{~mm}$ long; ventral process weakly bulging in lateral view and apically weakly curved; dorsal plate small and weakly bent in lateral view; flagellum moderately long, straight, slightly shorter and less slender than in P. crenulatus (Figs 18-19).

Etymology: The species is dedicated to Marc Tronquet, who collected most of the type specimens.

\section{Comparative notes:}

From all other species of the $P$. crenulatus group, $P$. tronquet $i$ is reliably distinguished only based on the morphology of the aedeagus, especially the apically weakly curved ventral process (lateral view) and the small dorsal plate.

\section{Distribution and bionomics:}

The distribution of this species appears to be confined to Corsica (Map 2). Most of the type specimens were collected on the wing in May. One paratype was taken in September. 
Proteinus hamatus sp. n. (Figs 20-21, Map 2)

\section{Type material:}

Holotype ơ: "E - No. 13, Castilla-Leon, Sierra de Urbión, Peńa Negra, 1950-2000 m, 4203N, 0266W, 15.X.2003, V. Assing / Holotypus ơ Proteinus hamatus sp. n. det. V. Assing 2007" (cAss). Paratypes: $20^{\top} 0^{\top}, 19$ : "E - No. 19, Castilla-Leon, 40 km ESE Burgos, Trigaza, $1950 \mathrm{~m}$, $42^{\circ} 15^{\prime} 25 \mathrm{~N}, 03^{\circ} 14^{\prime} 58 \mathrm{~W}, 17 . X .2003$, P. Wunderle" (cWun, cAss); $10^{\circ}$ : "E - No. 22, $40 \mathrm{~km} \mathrm{E}$ Teruel, Sierra de Gúdar, path $\rightarrow$ Peñarroya, $1890 \mathrm{~m}, 40^{\circ} 23^{\prime} 34 \mathrm{~N}, 00^{\circ} 39^{\prime} 09 \mathrm{~W}, 13 . \mathrm{IV} .2003$, P. Wunderle" (cWun); $20^{\star} \sigma^{\star}, 3$ 우 ㅇ: "France, Pyrénées-Orientales, La Preste, entée [sic] grotte En Brixtot, litière, M. Tronquet, 19.VI.2006" (cTro, cAss); $10^{\text {`: }}$ "Spain, La Granja / Proteinus crenulatus / Coll. G. A. Lohse MHNG - 1994" (MHNG).

\section{Description:}

2.2-2.7 mm (abdomen extended); width of pronotum: 0.60-0.75 mm. Coloration and other external characters as in P. crenulatus, distinguished only as follows:

Pronotum slightly more transverse, $1.65-1.75$ times as wide as long. $0^{*}$ : secondary sexual characters as in $P$. crenulatus. Aedeagus larger than in $P$. crenulatus, approximately $0.48 \mathrm{~mm}$ long; ventral process apically longer and more abruptly bent; dorsal plate larger and more strongly curved in lateral view; internal sac with very short flagellum and with additional rather large and dark membraneous structure (Figs 20-21).

Etymology: The name (Latin, adjective: hooked, hook-like) refers to the shape of the apex of the aedeagus.

\section{Comparative notes:}

From the other species of the $P$. crenulatus group, this species is distinguished by the larger aedeagus with an abruptly bent apex and internal structures of distinctive shape.

\section{Distribution and bionomics:}

The known distribution of this species is confined to southwestern France and northern Spain (Map 2); the locality "La Granja" is ambiguous and omitted from Map 2. The type specimens were collected in June and October, those taken by Paul Wunderle and myself were sifted from the litter below old pine trees at altitudes of 1890-2000 m.

\section{Acknowledgements}

I am indebted to all the colleagues indicated in the material section for the loan of material under their care. In particular, I am grateful to Marc Tronquet and Paul Wunderle for the generous gift of the holotypes of P. tronqueti and $P$. abditus, respectively, to the former also for supplying the photograph of the habitus of P. crenulatus. Benedikt Feldmann proof-read the manuscript.

\section{References}

Assing, V. 2004: New species and records of Staphylinidae from Greece (Insecta: Coleoptera). - Linzer biologische Beiträge 36: 593-613.

Dauphin, P. 1995a: Sur les Proteinus d'Europe occidentale (Coleoptera, Staphylinidae). - Bulletin de la Société Linnéenne de Bordeaux 23: 101-118.

Dauphin, P. 1995b: Description de Proteinus meuseli, nouvelle espèce d'Europe centrale (Coleoptera, Staphylinidae). - Bulletin de la Société Linnéenne de Bordeaux 23: 193-197. 
Dauphin, P. 1999: Description de deux nouveaux Proteinus méditerranéens (Coleoptera, Staphylinidae). - Bulletin de la Société Linnéenne de Bordeaux 27: 135-141.

Duverger, C. 1995: Laboulbéniales (Fungi Ascomycètes) parasites de Staphylinidae (Coleoptera) du sud-ouest de la France conservées dans la collection de l'auteur. - Bulletin de la Société Linnéenne de Bordeaux 23: 147-175.

Gusarov, V. 1989: Fauna i ekologiia stafilinid (Coleoptera, Staphylinidae) Kryma. Podsemeistva Metopsiinae, Proteinae [sic], Omaliinae, Piestinae, Tachyporinae, Oxyporinae, Steninae, Paederinae, Xantholininae, Staphylininae. - Vestnik Leningradskogo Universiteta. Biologii 1989 (3): 3-17.

Herman, L. H. 2001: Catalog of the Staphylinidae (Insecta: Coleoptera). 1758 to the end of the second millennium. Volumes I-VII. - Bulletin of the American Museum of Natural History 265: 4218 pp.

Horion, A. 1963: Faunistik der mitteleuropäischen Käfer. Staphylinidae. 1. Micropeplinae bis Euaesthetinae. - Überlingen-Bodensee, A. Feyel: xii + 412 pp.

Lattin, G. De 1967: Grundriss der Zoogeographie. - Stuttgart, Gustav Fischer: 602 pp.

Lohse, G. A. 1964: Fam. Staphylinidae I (Micropeplinae bis Tachyporinae). - In: Freude, H.; Harde, K. W. \& Lohse, G. A. (eds.): Die Käfer Mitteleuropas. Band 4. - Krefeld, Goecke \& Evers: 264 pp.

Pandellé, L. 1867: Synopsis des espèces françaises du genre Proteinus. Pp. 168-169. - In: Grenier, A.: Matériaux pour servir a la faune des coléoptères de France. - Paris, A. Grenier: 194 pp.

Smetana, A. 2004: Subfamily Proteininae Erichson, 1839. - In: Löbl, I. \& Smetana, A. (eds.): Catalogue of Palaearctic Coleoptera. Volume 2. Hydrophiloidea - Histeroidea - Staphylinoidea. - Apollo Books, Stenstrup: 579-624.

Author's address:

Dr. Volker Assing

Gabelsbergerstr. 2

30163 Hannover, Germany

e-mail: vassing.hann@t-online.de

\section{Subject editor:}

Dr. L. ZERChe 